WE have assessed the effect of platelet-activating factor (PAF), a biologically active phospholipid present in the human marrow, on the growth of human marrow and blood $\mathrm{CD}_{34}{ }^{+}$progenitors. While the metabolization rate of PAF by $\mathrm{CD}^{4} 4^{+}$cells is low (weak acetylhydrolase and acylation processes) it is readily catabolized by the acetylhydrolase activity present in the growth medium $(10 \%$ fetal calf serum $+10 \%$ 5637 -conditioned medium). Treatment of marrow $\mathrm{CD}^{4} 4^{+}$cells with the non-metabolizable PAF agonist C-PAF ( $1 \mathrm{nM}$ to $100 \mathrm{nM}$ ) im mediately before semi-solid culture significantly $(P<0.01)$ decreased the number of BFU-E but not of CFU-GM colonies. Treatment of marrow or blood CD34 $4^{+}$cells with C-PAF (10-100 n M) for 3 days in liquid medium before semi-solid culture significantly $(P<0.01)$ decreased the number of BFU$E$ and CFU-GM colonies. Treatment of blood CD34 ${ }^{+}$ cells with the two PAF receptor antagonists CV 3988 and $B N 52021(1 \mu M)$ had no significant effect on the number of BFU-E and CFU-GM colonies suggesting no role of endogenous PAF in these processes. These results show that exogenous PAF downregulates human erythropoies is and myelopoiesis, a result that might be of importance during inflammatory states.

Key words: PAF, CD $34^{+}$cells, Myeloid progenitor, Erythroid progenitor

\section{Effect of platelet-activating factor on the growth of human erythroid and myeloid $\mathrm{CD}_{3} 4^{+}$progenitors}

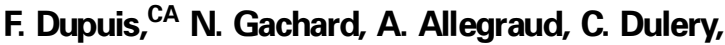 \\ V. Praloran and Y. Denizot
}

Laboratoire d'Hématologie Expérimentale, Faculté de Médecine, 2 rue Dr Marcland, 87025 Limoges, France

${ }^{\mathrm{CA}}$ Corresponding Author
Tel: $(+33) 0555435867$
Fax: $(+33) 0555435866$

\section{Introduction}

Studies highlight the role of lipidic compounds on human haematopoiesis. ${ }^{1-6}$ They demonstrate that leukotrienes and prostaglandin $\mathrm{E}$ upregulate and downregulate human myelopoiesis, respectively. By contrast leukotrienes and prostaglandin $\mathrm{E}$ downregulate and upregulate human erythropoiesis, respectively. Platelet-activating factor (PAF) is a phospholipid molecule produced by inflammatory stimulated cells. ${ }^{7}$ PAF levels are regulated by an acetylhydrolase activity (AHA) which converts PAF into lyso PAF which is then reacylated into membrane phospholipids by an acyltransferase activity (ATA). ${ }^{7}$ Numerous studies report the immunoregulatory properties of PAF. Its inhibiting or activating effects are shown in various cell types such as monocytes/ macrophages, polymorphonuclear neutrophils, eosinophils and T- and B-ymphocytes. ${ }^{7-9}$ Studies report that complex interrelations exist between PAF and cytokines. Thus, PAF stimulates the production of several cytokines such as interleukin (IL)-1, IL-6 and tumour necrosis factor-alpha (TNF- $\alpha$ ) which, in turn, may enhance PAF synthesis. ${ }^{7-9}$

While PAF is present in the human bone marrow, ${ }^{10,11}$ its effects on the growth of myeloid and erythroid progenitors is not documented. CD34, a surface antigen expressed on haemopoietic stem/ progenitor cells that disappears at later stages of differentiation can be used to select this population. ${ }^{12,13}$ In this study we have examined the effect of PAF on human haematopoiesis by investigating its effects on the growth of granulocyte-macrophage (CFU-GM) and erythroid progenitor cells (BFU-E) from purified human marrow and blood $\mathrm{CD} 34^{+}$ cells. We also examined PAF metabolism by $\mathrm{CD} 34^{+}$ cells.

\section{Materials and Methods}

\section{Collection and preparation of mononuclear cells}

Sternum bone marrow cells were harvested by aspiration into heparinized tubes (Vacutainer system, Becton Dickinson, Meylan, France) from patients referred for diagnosis according to the Helsinki recommendations. Mononuclear cells were isolated by separation on a Ficoll gradient $(400 \times \mathbf{g}, 20 \mathrm{~min})$ and washed twice with Hanks's balanced salts solution (Gibco, Cergy Pontoise, France). None of these patients had an haematological malignancy and their myelograms were normal. Peripheral blood stem cells were collected from lymphoma patients in complete remission undergoing apheresis for autologous trans- 
plantation. Several aliquots used for bacteriological and CFU-GM controls were harvested in freezing tubes from the final apheresis product just before freezing. They were then stored in liquid nitrogen with apheresis autograft bags until used.

\section{Selection of $\mathrm{CD}_{3} 4^{+}$cells}

Mononuclear bone marrow cells were used immediately after Ficoll and washing procedures. Peripheral blood stem cells were rapidly defreezed in a $37^{\circ} \mathrm{C}$ water bath, then diluted and washed in saline with $4 \%$ human serum albumin (HSA). CD34 $4^{+}$cells were obtained by magnetic cell sorting (MiniMACS, Tebu, Le Perray en Yvelines, France) as previously described. ${ }^{14}$ The entire procedure was made according to the manufacturer's instructions. Briefly, cells were resuspended at a concentration of $1 \times 10^{8} / 0.3 \mathrm{ml}$. The blocking reagent and the antibody reagent $(0.1 \mathrm{ml}$ for $1 \times 10^{8}$ cells) were added to the cell suspension and incubated at $4^{\circ} \mathrm{C}$ for $15 \mathrm{~min}$. Cells were then washed with $4 \mathrm{ml}$ of washing buffer (PBS/0.5\% human serum albumin (HSA) $/ 5 \mathrm{mM}$ EDTA) and centrifuged. Cells were recovered in cold washing buffer $(0.4 \mathrm{ml}$ for $1 \times$ $10^{8}$ cells) and incubated with a suspension of submicroscopic magnetic beads $\left(0.1 \mathrm{ml}\right.$ for $1 \times 10^{8}$ cells) for $15 \mathrm{~min}$ at $4^{\circ} \mathrm{C}$. After washing, cells were recovered in $0.5 \mathrm{ml}$ of cold washing buffer, filtered, applied to the separation column previously placed in a magnetic field, and washed with $2 \mathrm{ml}$ of buffer. Cells which did not bind $\mathrm{CD} 34^{+}$antibody passed through the column while $\mathrm{CD} 34^{+}$cells were retained. The $\mathrm{CD} 34^{+}$cells were eluted by removing the column from the magnetic field and washing the column with $1 \mathrm{ml}$ buffer. After a new step of washing $\mathrm{CD} 34^{+}$cells were recovered in IMDM and counted.

\section{Flow cytometric analysis of selected CD34 ${ }^{+}$ cells}

Samples were analysed on a Profile Coulter using Epics Profile Software to determine the efficiency of the selection. One-hundred $\mu 1$ of cell suspension was incubated at room temperature for $30 \mathrm{~min}$ with $5 \mu \mathrm{l}$ phycoerythrin (PE)-labelled anti-CD34 (HPCA-2) monoclonal antibody or PElabelled monoclonal control (mouse immunoglobulin) and washed twice with PBS supplemented with 2\% HSA. Fixation with paraformaldehyde (PFA 1\%) was performed at the end of staining. The purified population contained $84 \pm$ $2 \%$ of $\mathrm{CD}^{2} 4^{+}$cells (mean \pm SEM of 17 experiments, range $72-98 \%$ ).

\section{Semisolid cultures}

Two experimental conditions were used for $\mathrm{CD} 34^{+}$ cells. Firstly, freshly isolated marrow $\mathrm{CD} 34^{+}$cells were incubated $30 \mathrm{~min}$ at $37^{\circ} \mathrm{C}$ in $1 \mathrm{ml} \mathrm{IMDM}$ with various concentrations of PAF (Sigma, St QuentinFallavier, France) and of the non-metabolizable PAF agonist 1-O-hexadecyl-2-N-methycarbamyl-sn-glycero3-phosphocholine (C-PAF) (Sigma) before methylcellulose culture. Secondly, freshly isolated marrow $\mathrm{CD} 34^{+}$cells and frozen blood mononuclear CD $34^{+}$ cells were grown for 3 days in liquid medium with various concentrations of PAF, C-PAF, CV 3988 and BN 52021 (two potent PAF receptor antagonists) (Tebu) or the appropriate vehicle ( $10 \mu \mathrm{l}$ of $2 \% \mathrm{HSA})$ before colony formation in methylcellulose cultures. Marrow or blood $\mathrm{CD} 34^{+}$cells $\left(4 \times 10^{3}\right)$ were grown in 96-round-bottomed well microtitre plates in $100 \mu \mathrm{l}$ IMDM with $10 \%$ fetal calf serum (FCS) (Gibco), 10\% 5637 -conditioned medium and antibiotics $(100 \mathrm{U} / \mathrm{ml}$ penicillin and $100 \mu \mathrm{g} / \mathrm{ml}$ streptomycin) at $37^{\circ} \mathrm{C}$ in $5 \%$ $\mathrm{CO}_{2}$ in air.

Colony assays were performed in both experiments with $\mathrm{CD} 34^{+}$cells $\left(5 \times 10^{2}\right)$ cultured in $35 \mathrm{~mm}$ Petri dishes in sixplicates for 14 days at $37^{\circ} \mathrm{C}$ in $5 \% \mathrm{CO}_{2}$ in air in $100 \%$ humidity. The culture medium $(1 \mathrm{ml} /$ dish $)$ was a mixture of IMDM with $0.8 \%$ methylcellulose, 30\% FCS, $1 \%$ detoxified bovine serum albumin, $10 \mathrm{ng} / \mathrm{ml}$ Stem Cell Factor (Tebu), $40 \mathrm{ng} / \mathrm{ml}$ interleukin-3 (Sandoz, Rueil-Malmaison, France), $3 \mathrm{U} / \mathrm{ml}$ erythropoietin (R\&D systems, Oxfordshire, UK), $\alpha$-thioglycerol $(0.1 \mathrm{mM})$ and $10 \%$ 5637-conditioned medium. CFU-GM and BFU-E derived colonies were counted under an inverted microscope in the same dish. The differences of colony number between controls and test dishes were analysed using Wilcoxon's test.

\section{$\left[{ }^{3} \mathrm{H}\right] \mathrm{PAF}$ metabolism and AHA assay}

$\mathrm{CD} 34^{+}$cells $\left(1 \times 10^{5}\right)$ were washed twice with $\mathrm{HBSS}$ and were incubated at $37^{\circ} \mathrm{C}$ in $1 \mathrm{ml}$ of IMDM for various periods of time in the presence of $\left[{ }^{3} \mathrm{H}\right]$ alkylPAF (final concentration $0.05 \mathrm{nmol} /$ tube; $0.5 \mu \mathrm{Gi}$ ) (Amersham) complexed to HSA (final concentration $2 \mathrm{mg} / \mathrm{ml}$ ). Experiments were performed in duplicate. The PAF metabolism was assessed after lipid extraction. ${ }^{15}$ Recovery of added radioactivity after lipid extraction was $85 \%$ The labelled compounds derived from $\left[{ }^{3} \mathrm{H}\right]$ alkyl-PAF were separated using TLC plates $($ Silica Gel $60(20 \times 20 \mathrm{~cm}, 0.25 \mathrm{~mm}))$ eluted with chloroform/methanol/acetic acid/water (50:25:8:4, $\mathrm{v} / \mathrm{v}) .{ }^{11}$ Each lane was divided in areas of $0.5 \mathrm{~cm}$ length which were scraped into vials and radioactivity was measured on a Packard liquid scintillation counter. PAF, lyso PAF, phosphatidylcholine (PC) and neutral lipid (NL) were used as standards. AHA was assessed in culture medium according to the method of Miwa et $a l .{ }^{16}$ Results were expressed as picomoles PAF degraded per min per $\mathrm{ml}$ as means of duplicate determinations. The variation between duplicates was less than $5 \%$ 


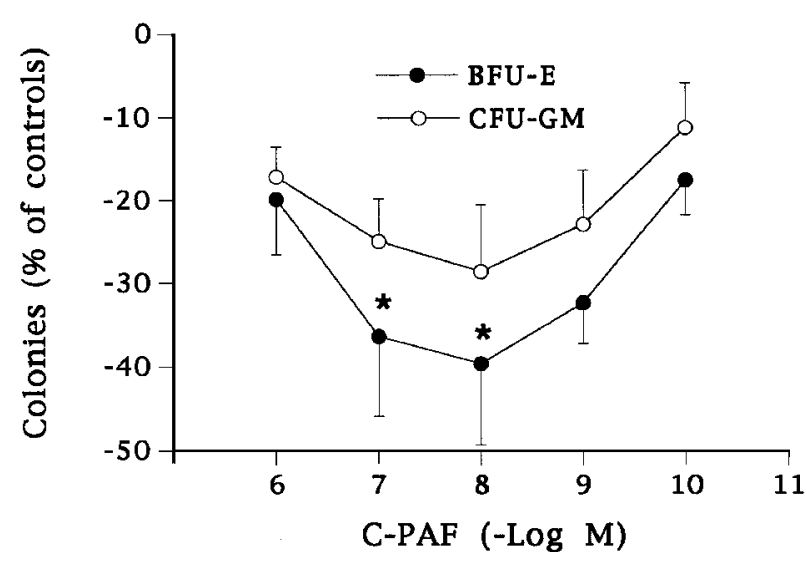

FIG. 1. Direct effect of C-PAF on the number of BFU-E and CFU-GM colonies derived from freshly isolated marrow $\mathrm{CD}_{3}{ }^{+}$cells. Percentage of variation of colony numbers compared with control values (seven independent experiments). ${ }^{*} P<0.01$ (Wilcoxon's test). Colony numbers in controls were $37 \pm 7$ and $85 \pm 11$ for BFU-E and CFU-GM, respectively.

\section{Results}

We first investigated PAF catabolism by human $\mathrm{CD} 34^{+}$ cells. Cells were incubated with $\left[{ }^{3} \mathrm{H}\right]$ alkyl PAF in IMDM alone. After $24 \mathrm{~h}$ of incubation 73\% 18\%,5\% and $4 \%$ of the label migrated with PAF, lyso PAF, 1-alkyl analogue of PC and NL, respectively (mean of three experiments). When cells were incubated in IMDM + $10 \%$ FCS + 10\% 5637-conditioned medium (growth medium), $0 \%, 90 \%, 6 \%$ and $4 \%$ of the label migrated with PAF, lyso PAF, 1-alkyl analogue of PC and NL, respectively. After $1 \mathrm{~h}$ of incubation in growth medium, $100 \%$ of the $\left[{ }^{3} \mathrm{H}\right] \mathrm{PAF}$ was converted into $\left[{ }^{3} \mathrm{H}\right]$ lyso PAF demonstrating a high AHA. The mean AHA levels detected in IMDM with $10 \%$ 5637-conditioned medium, 10\% FCS, and 10\% 5637-conditioned medium $+10 \%$ FCS were $204 \pm 16,1676 \pm$ 190 and $2160 \pm 115 \mathrm{pmol} / \mathrm{min} / \mathrm{ml}$, respectively (mean \pm SEM of three experiments). No significant AHA was detected in IMDM alone.

We next assessed the effect of PAF and C-PAF on the grow th of human CFU-GMand BFU-E. Due to its rapid metabolism, no significant effect was found with PAF. By contrast treatment of marrow $\mathrm{CD} 34^{+}$cells with the non-metabolized PAF agonist C-PAF (1-100 nM) significantly $(P<0.01$, seven independent experiments) decreased the number of BFU-E but not of CFU-GM colonies (Fig. 1). Treatment of marrow $\mathrm{CD} 4^{+}$cells with C-PAF (10-100 nM) for 3 days in liquid medium before semi solid cultures, significantly $(P<0.01$, three independent experiments) decreased the number of BFU-E and CFU-GMcolonies (Fig. 2A). In similar experimental conditions, C-PAF significantly $(P<$ 0.01 , three independent experiments) decreased the grow th of BFU-E and CFU-GM colonies from blood $\mathrm{CD}^{2} 4^{+}$cells (Fig. 2B). In these experimental conditions the PAF receptor antagonist CV $3988(1 \mu \mathrm{M})$
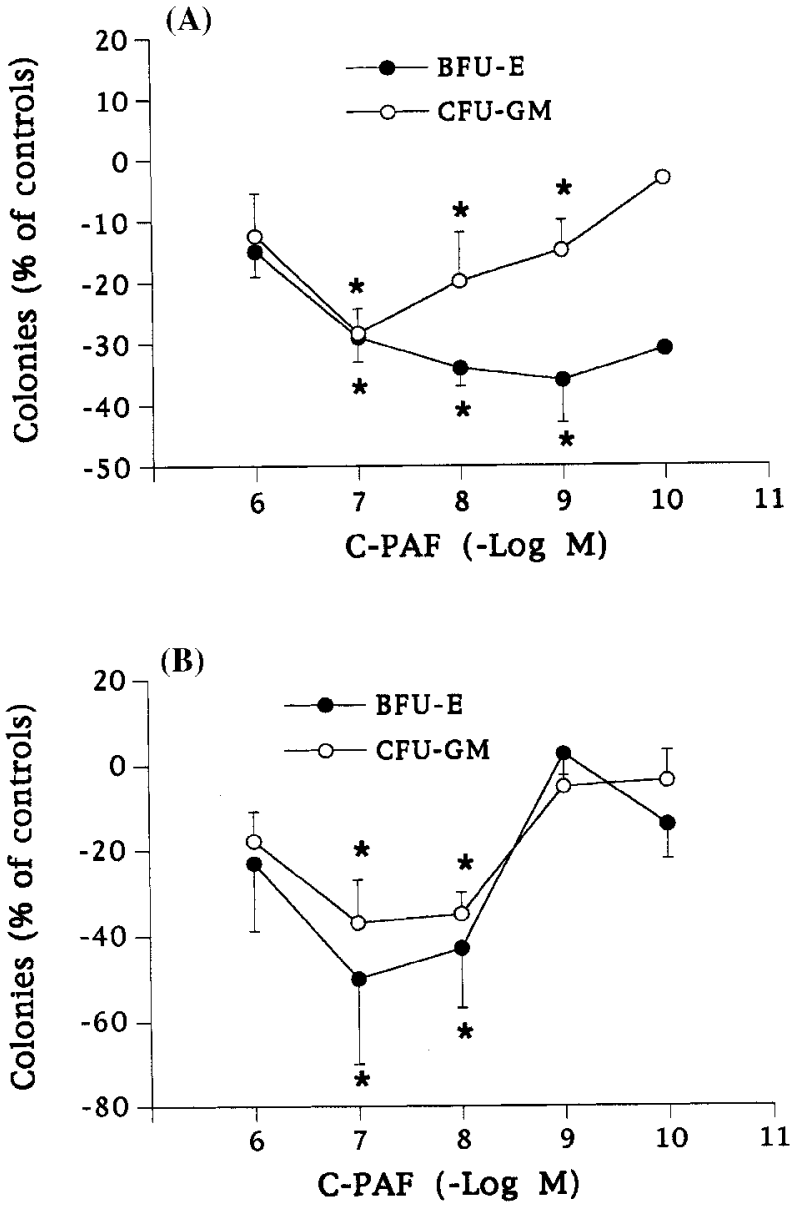

FIG. 2. Effect of C-PAF on the growth of BFU-E and CFU-GM colonies from marrow $(A)$ and blood (B) $C D 34^{+}$cells cultured 3 days in liquid medium before colony assay. (A) Percentage of variation of colony numbers compared with control values (three independent experiments). ${ }^{*} P<0.01$ (Wilcoxon's test). Colony numbers in controls were $28 \pm 4$ and $51 \pm 3$ for BFU-E and CFU-GM, respectively. (B) Percentage of variation of colony number compared with control values (three independent experiments). ${ }^{*} P<0.01$ (Wilcoxon's test). Colony number in controls were $16 \pm 2$ and $37 \pm 3$ for BFU-E and CFU-GM, respectively.

slightly $(P<0.05$, four independent experiments $)$ enhanced the grow th of BFU-E colonies compared with control dishes $(23 \pm 2$ colonies vs. $19 \pm 2$ colonies for CV 3988-treated cells and controls, respectively) while BN $52021(1 \mu \mathrm{M})$ had no effect $(20 \pm 2$ colonies). CV 3988 and BN 52021 had no effect on CFU-GMgrow th $(54 \pm 5$ colonies and $56 \pm 5$ colonies vs. $52 \pm 5$ colonies for CV 3988-treated cells, BN 52021-treated cells and controls, respectively).

\section{Discussion}

Lipidic mediators (such as prostaglandins and leukotrienes) affect the grow th of human CFU-GMand BFUE progenitors. ${ }^{1-6}$ The rationale for analysing the role of PAF on the grow th of human myeloid and erythroid progenitors is based on several points. First, PAF is 
present in the human bone marrow. ${ }^{10,11}$ Second, PAF modulates the growth of various human cell types including adherent bone marrow cells. ${ }^{17}$ Third, PAF stimulates the eosinophilic and basophilic differentiation from human blood progenitors. ${ }^{18}$ Finally, PAF increases the erythroid colony formation from cultured $\mathrm{CD}_{3} 4^{+}$haematopoietic progenitors by enhancing the prolactin synthesis by human bone marrow stromal cell feeders. ${ }^{19}$

The use of the CD34 antigen is a useful way to obtain haematopoietic stem/progenitor cells. ${ }^{12,13}$ It is expressed on $1-3 \%$ of adult bone marrow cells, ${ }^{20}$ and about $0.1 \%$ of normal blood mononuclear cells. ${ }^{21}$ As the population of bone marrow $\mathrm{CD} 34^{+}$progenitors differ from that in blood by a higher percentage of more commited progenitors, ${ }^{22}$ we have investigated the effect of PAF on both marrow and blood CD $34^{+}$ cells. Our percentage of $\mathrm{CD} 34^{+}$cells after magnetic cell sorting is similar to recent studies using this method. ${ }^{14,23}$ All $\mathrm{CD} 34^{+}$cells are not haematopoietic progenitors. Thus, cells that give rise to fibroblast-like stromal elements of the bone marrow may be recovered in the $\mathrm{CD} 34^{+}$cell fraction but represent less than $5 \%$ of total CD34 $4^{+}$cells. ${ }^{24}$ Moreover colonies of fibroblastic cells were not documented in our $\mathrm{CD} 34^{+}$cell cultures.

Our studies are done with a non-metabolizable PAF agonist since PAF is readily catabolized by an AHA present in the culture medium. By contrast the metabolization rate of PAF by human $\mathrm{CD} 34^{+}$cells is low (weak intracellular AHA and ATA). The nanomolar concentrations of C-PAF active in this study are physiologically significant since PAF is detected in the human marrow at a mean level of about $1 \mathrm{nM}^{11}$ The use of $1 \mathrm{nM}$ of C-PAF may be compared with a continuous stimulation with this physiologic dose of PAF. In the present study treatment of marrow CD $34^{+}$ cells with C-PAF immediately before semi solid culture decreased the grow th of BFU-E but not of CFU-GM colonies suggesting a direct effect of C-PAF on human erythroid progenitor cells. An effect of C-PAF on marrow or blood CFU-GM colonies was found after 3 days of treatment in liquid medium before semi solid culture suggesting an indirect effect through an elevated production of inhibitory factor(s) or a decreased production of stimulatory factor(s). In vitro studies report that PAF modulates the production of several molecules such as IL-1, IL-3, IL-4, IL-6, TNF- $\alpha$, prostaglandins and leukotrienes that regulate human CFU-GM grow th. ${ }^{7-9,25}$ No role of endogenous PAF may be documented on the growth of CD34 ${ }^{+}$ cells. Thus, the two PAF receptor antagonists CV 3988 and BN 52021 have no effect on the number of CFUGM colonies. In contrast to BN 52021, CV 3988 has a weak effect on BFU-E colonies. A similar difference between these two drugs has been found concerning their ability to inhibit superoxide anion generation in a human B cell line. ${ }^{26}$ In this previous study the weak effect of CV 3988 was attributed to its incorporation in cell membrane leading to a non-specific effect. Such an effect may also be suggested in our study.

Bellone et al. ${ }^{19}$ have recently reported that PAF stimulates the erythroid colony formation from $\mathrm{CD} 34^{+}$haematopoietic progenitors by enhancing the prolactin synthesis by human bone marrow stromal cells. Our present results indicate that, in absence of a marrow stromal cell feeder, PAF decreases the grow th of erythroid and myeloid $\mathrm{CD} 34^{+}$progenitors highlighting not only the putative role of PAF during early steps of human haematopoiesis but also the complexity of the regulation of the bone marrow progenitor growth.

\section{References}

1. Claesson HE, Nadlberg N, Gahrton G. Stimulation of human myelopoiesis by leukotriene $\mathrm{B}_{4}$. Biochem Biophys Res Commun 1985; 131: 579-585.

2. Lu L, Broxmeyer HE. Comparative influence of phytohemagglutininstimulated leukocyte conditioned medium, hemin, prostaglandin E, and low oxygen tension on colony formation by erythroid progenitor cells in normal human bone marrow. Exp Hematol 1985; 13: 989-993.

3. Miller AM, Weiner RS, Ziboh VA. Evidence for the role of leukotrienes $\mathrm{C}_{4}$ and $\mathrm{D}_{4}$ as essential intermediates in CSF-stimulated human myeloid colony formation. Exp Hematol 1986; 14: 760-765.

4. Pasquale D, Chikkappa G. Lipoxygenase products regulate proliferation of granulocyte-macrophage progenitors. Exp Hematol 1993; 21: 1361-1365.

5. Rossi GB, Migliaccio AR, Migliaccio G, Lettieri F, Di Rosa M, Mastroberardino G, Peschle C. In vitro interactions of PGE and cAMP with murine and human erythroid precursors. Blood 1980; 56: 74-79.

6. Stenke L, Mansour M, Reizenstein P, Lindgren JA. Stimulation of human myelopoiesis by leukotrienes $\mathrm{B}_{4}$ and $\mathrm{C}_{4}$ : interactions with granulocytemacrophage colony stimulating factor. Blood 1993; 81: 352-356.

7. Denizot Y. Platelet-activating factor: biosynthesis, biodegradation, actions. In: v. Bruchhausen F, Walter U, eds. Handbook of Experimental Pharmacology: Platelets and their Factors. Heidelberg: Springer 1997; 126: 483-506.

8. Braquet P, Rola-Pleszczynski M Patelet-activating factor and cellular immune responses. Immunol Today 1987; 8: 345-352.

9. Bonavida B, Mencia-Huerta JM. Platelet-activating factor and the cytokine network in inflammatory processes. Clin Rev Allergy 1995; 12: 381-395.

10. Denizot Y, Charissoux JL, Nathan N, Praloran V. PAF and haematopoiesis: V. Platelet-activating factor and acetylhydrolase in human femoral bone marrow. J Lipid Mediators Cell Signalling 1995; 12: 45-47.

11. Denizot Y, Trimoreau F, Dupuis F, Verger C, Praloran V. PAF and haematopoiesis. III. Presence and metabolism of platelet-activating factor in human bone marrow. Biochem Biophys Acta 1995; 1265: 55-60.

12. Holyoake TL, Alcorn MJ. CD34 $4^{+}$positive haemopoietic cells: biology and clinical applications. Blood Rev 1994; 8: 113-124.

13. Krause DS, Fackler M, Civin C, May WS. CD34: Structure, biology, and clinical utility. Blood 1996; 87: 1-13.

14. De Wynter EA, Coutinho LH, Pei X, Marsh JCW, Hows J, Luft T, Testa NG. Comparison of purity and enrichment of CD34+ cells from bone marrow, umbilical cord and peripheral blood (primed for apheresis) using five separation systems. Stem Cells 1995; 13: 524-532.

15. Bligh ML, Dyer WJ. A rapid method of total lipid extraction and purification. Can J Biochem 1959; 37: 911-917.

16. Miwa M, Miyake T, Yamanaka T, Sugatani J, Suzuki Y, Sakata S, Araki Y, Matsumoto M. Characterization of serum platelet-activating factor (PAF) ace tylhydrolase. Correlation between deficiency of serum PAF acetylhydrolase and respiratory symptoms in asthmatic children. J Clin Invest 1988; 82: 1983-1991.

17. Denizot Y, Dupuis F, Trimoreau F, Verger C, Allegraud A, Praloran V. PAF and haematopoiesis: IX. Platelet-activating factor increases DNA synthesis in human bone marrow cells. J Lipid Mediators Cell Signalling 1996; 15: $1-4$.

18. Saito H, Hayakawa T, Mita H, Akiyama K, Shida T. PAF-induced eosinophilic and basophilic differentiation in human hematopoietic precursor cells. J Lipid Mediators 1992; 5: 135-137.

19. Bellone G, Astarita P, Artusio E, Silvestri S, Mareschi K, Turletti A, Buttiglieri S, Emanuelli G, Matera L. Bone marrow stroma-derived prolactin is involved in basal and platelet-activating factor-stimulated in vitro erythropoiesis. Blood 1997; 90: 21-27. 
20. Andrews RG, Singer JW, Bernstein ID. Monoclonal antibody 12-8 recognizes a $11-\mathrm{Kd}$ molecule present on both unipotent and multipotent hematopoietic colonyforming cells and their precursors. Blood 1986; 67: $842-845$.

21. Bender JG, Unverzagt KL, Walker DE, Lee W, Van Epps DE, Smith DH, Stewart CC, To LB. Identification and comparison of CD34-positive cells and their subpopulations from normal peripheral blood and bone marrow using multicolor flow cytometry. Blood 1991; 77: 2591-2596.

22. Wickenhauser C, Thiele J, Drebber U, Kvasnicka HM, Thiel A, Schmitz B, Hansmann ML, Fischer R. CD34 ${ }^{+}$human hemopoietic progenitor cells of the bone marrow differ from those of the peripheral blood: an immunocytochemical and morphometric study. Acta Haematol 1995; 93: 83-90.

23. Servida F, Soligo D, Caneva L, Bertolini F, de Harven E, Campiglio S, Corsini C, Lambertenghi Deliliers G. Functional and morphological characterization of immunomagnetically selected $\mathrm{CD} 34^{+}$hematopoietic progenitor cells. Stem Cells 1996; 14: 430-438.
24. Simmons PJ, Torok-Storb B. CD34 expression by stromal precursors in normal human adult bone marrow. Blood 1991; 78: 2848-2853.

25. Rola-Pleszczynski M, Thivierge M, Gagnon N, Lacasse C, Stankova J Differential regulation of cytokine and cytokine receptor genes by PAF LTB4 and PGE2. J Lipid Mediators 1993; 6: 175-181.

26. Leca G, Joly F, Vazquez A, Galanaud P, Ninio E. Paf-acether-induced superoxide anion generation in human B cell line. FEBS Lett 1990; 269: $171-173$.

ACKNOWLEDGEMENTS. FD. was supported by a grant from the Association pour la Recherche sur le Cancer (ARC). This paper is number 16 of a series: $\mathrm{PAF}$ and haematopoiesis.

\section{Received 2 December 1997;} accepted 9 January 1998 


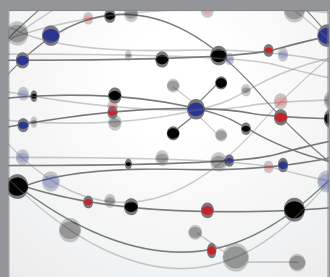

The Scientific World Journal
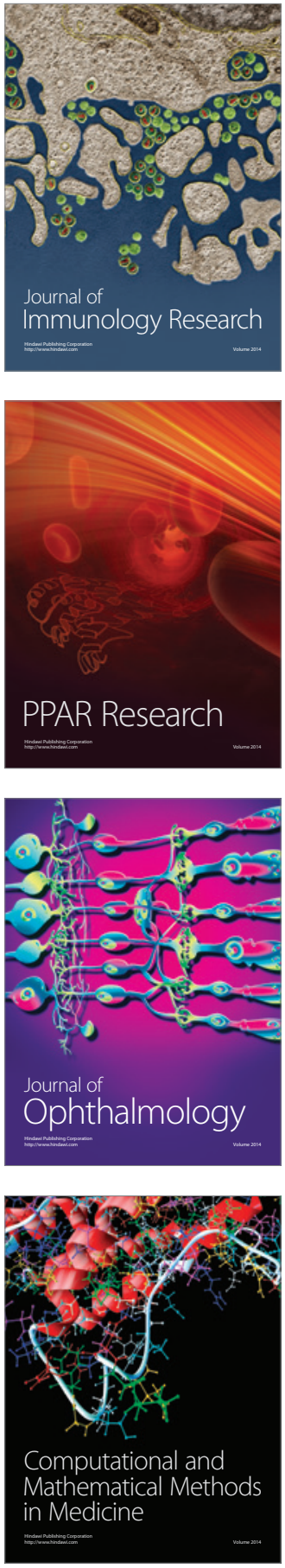

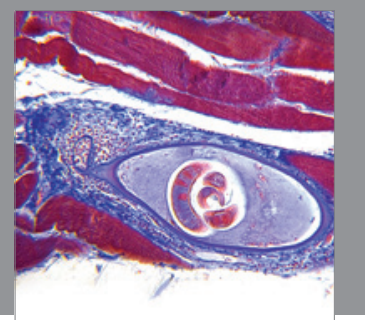

Gastroenterology

Research and Practice
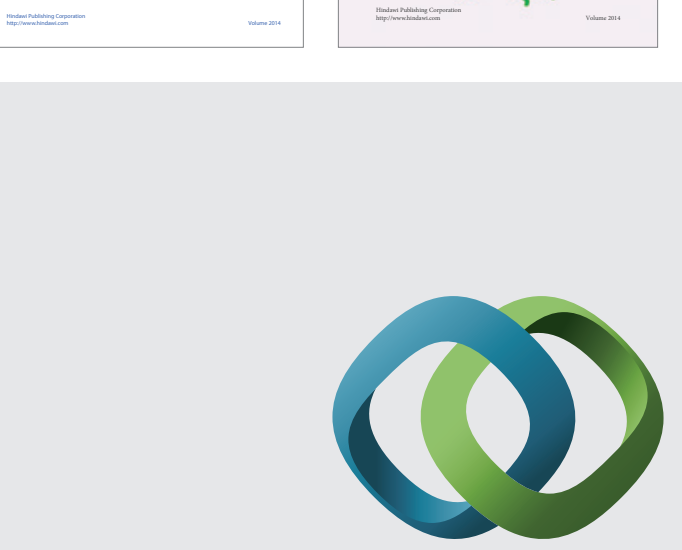

\section{Hindawi}

Submit your manuscripts at

http://www.hindawi.com
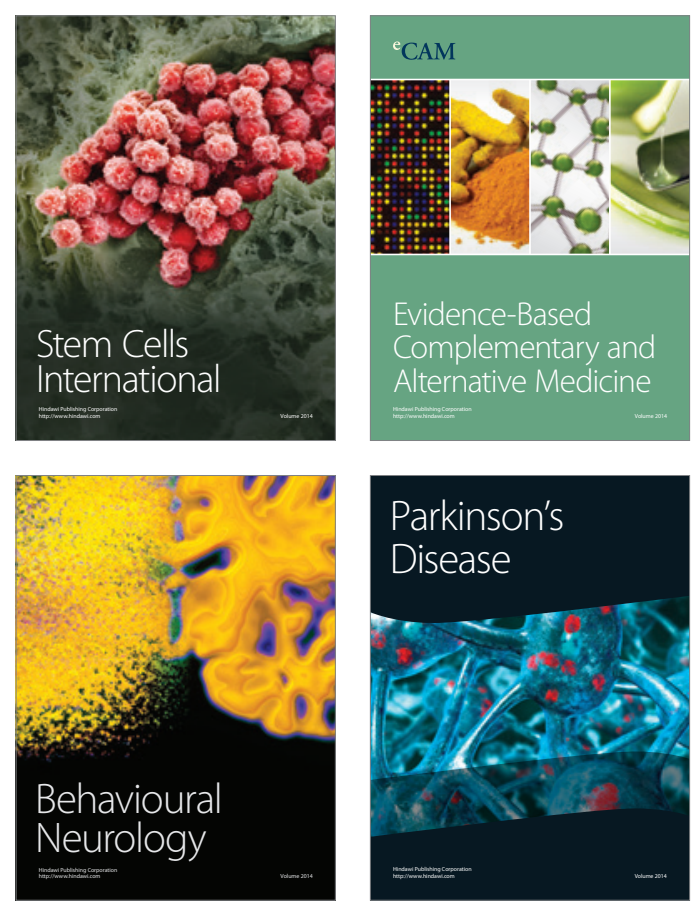

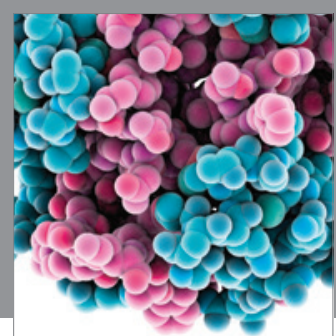

Journal of
Diabetes Research

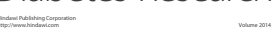

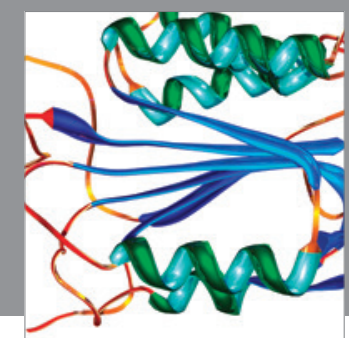

Disease Markers
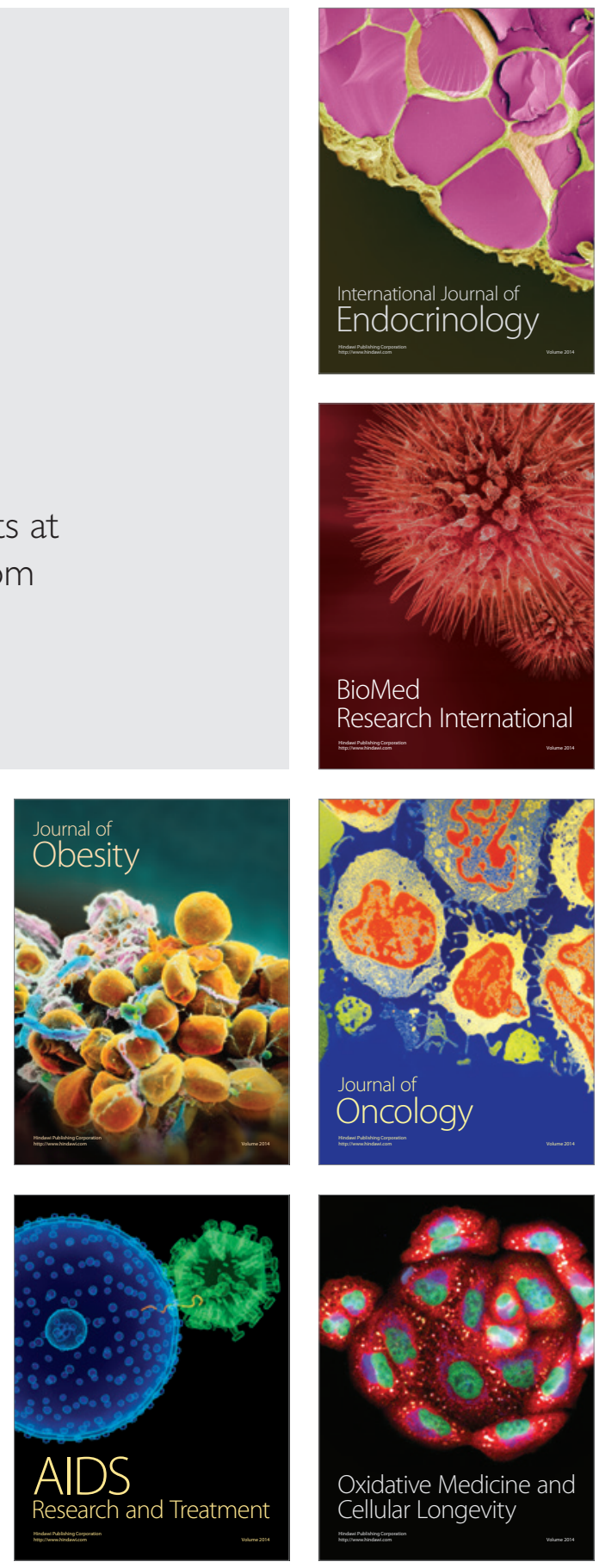